\title{
FACTORS ASSOCIATED WITH LONG DIAGNOSTIC DELAY IN CELIAC DISEASE
}

Valma Fuchs

Syventävien opintojen kirjallinen työ

Tampereen Yliopisto

Lääketieteen yksikkö

Keliakiatutkimusryhmä

Toukokuu 2014 
Tampereen yliopisto

Lääketieteen yksikkö

Keliakiatutkimusryhmä

VALMA FUCHS: FACTORS ASSOCIATED WITH LONG DIAGNOSTIC DELAY

IN CELIAC DISEASE

Kirjallinen työ, 14 sivua

Ohjaaja: Professori Katri Kaukinen ja dosentti Kalle Kurppa

Toukokuu 2014

Avainsanat: keliakia, diagnoosiviive, aikuiset, Käypä hoito -suositus

Selvitimme keliakian diagnoosiviiveeseen liittyviä tekijöitä sekä keliakian Käypä hoito -suosituksen osuutta diagnoosiviiveen lyhenemiseen.

Tämä retrospektiivinen kohorttitutkimus koostui 825 aikuisesta suolinäytteen perusteella diagnosoidusta keliaakikosta. Diagnoosi määriteltiin viivästyneeksi, kun kesto oireiden alkamisesta diagnoosihetkeen oli yli kymmenen vuotta. Tutkittavilta kerättiin tietoa oireiden tyypistä ja kestosta ennen diagnoosia, diagnoosipaikasta (primaari-, sekundaari- vai tertiaarisairaanhoito), diagnoosiajankohdasta, keliakian sukutaustasta sekä merkittävistä keliakiaan liittyvistä sairauksista. Analyysi toteutettiin binaarisella logistisella regressiolla.

Yhteensä 261:1la (32\%) 825:sta tutkittavasta oli yli kymmenen vuotta kestävä diagnoosiviive. Naissukupuoli, neurologinen tai tuki- ja liikuntaelinsairaus, ripuli, vatsakipu sekä imeytymishäiriöt olivat yhteydessä pitkittyneeseen viiveeseen. Miessukupuoli, diagnoosi keliakian Käypä hoito suosituksen julkistamisen jälkeen, seulottu keliakia sekä keliakian sukutausta olivat yhteydessä pienempään diagnoosiviiveen riskiin. Diagnoosipaikka, tutkittavan ikä, dermatitis herpetiformis, tyypin 1 diabetes sekä kilpirauhassairaus eivät olleet yhteydessä diagnoosiviiveeseen.

Viivästyneet keliakiadiagnoosit ovat vähentyneet viime vuosikymmeninä. Diagnostiikan siirtyminen erikoissairaanhoidosta perusterveydenhuoltoon ei ole vaikuttanut viiveeseen. Keliakian Käypä hoito suositus sekä aktiivinen riskiryhmien seulonta on vaikuttanut merkittävästi näihin tuloksiin. 


\section{SISÄLLYSLUETTELO}

Abstract




\title{
ABSTRACT
}

Objective. We here investigated the factors associated with long diagnostic delay in celiac disease and the impact of the national Current Care Guidelines in reducing the delay.

Material and methods. This population-based study involved 825 adult celiac disease patients. The diagnosis was considered delayed when the interval between first symptoms and diagnosis was more than 10 years. The patients were asked about the duration and type of symptoms before diagnosis, time and site (tertiary, secondary or primary care) of the diagnosis, family history of the disease and presence of significant co-morbidities. Analysis was performed by binary logistic regression.

Results. Altogether 261 (32\%) out of 825 participants reposted a diagnostic delay of more than 10 years. Female gender, neurologic or musculoskeletal disorders and presence of diarrhea, abdominal pain and malabsorption were associated with prolonged delay. Male gender, diagnosis after the introduction of the first Current Care Guidelines in 1997 and being detected by serologic screening and family history of celiac disease were associated with a lower risk of delayed diagnosis. Factors not associated with the delay were site of diagnosis, age, presence of dermatitis herpetiformis, type 1 diabetes or thyroidal disease.

Conclusions. The number of long diagnostic delays in celiac disease has decreased over the past decades. The shift of diagnostics from secondary and tertiary care to primary care has not been detrimental. National guidelines for the diagnosis and active screening in at-risk groups are important in these circumstances.

\author{
Abbreviations: OR, Odds Ratio
}

Key Words: Celiac disease, Diagnostic delay, Current Care Guidelines, Adults 


\section{INTRODUCTION}

In recent years the diverse clinical presentation of celiac disease has been recognized. Classical symptoms are diarrhea and poor growth or weight loss, but a variety of extraintestinal and atypical presentations are becoming increasingly common [1]. The heterogeneous clinical picture constitutes a challenge to physicians, and the average diagnostic delay is indeed very long, up to 12 years [2-7]. Besides the burden inherent in the ongoing symptoms, unrecognized celiac disease is associated with excessive use of health care services and on-demand medications $[4,8,9]$. Further, untreated disease predisposes to complications such as osteoporotic fractures [10], infertility [11, 12] and intestinal lymphoma $[13,14]$. An early initiated gluten-free diet reduces the incremental burden to health care and the risk of complications and also improves health-related quality of life $[2,5,8,15]$.

In Finland, nationwide guidelines for the diagnosis and treatment of celiac disease were published in 1997 and are regularly updated [16]. The primary aims of the guidelines were to increase the diagnostic yield and to shift diagnostics from secondary and tertiary centres to primary care. General practitioners in primary care are systematically trained to maintain a low threshold for celiac disease suspicion and recognize patients with mild or atypical symptoms [17]. A decrease in diagnostic delay is one expected consequence of the revised clinical practice $[16,18]$. Indeed, since the guidelines were launched, the prevalence of biopsy-proven celiac disease has increased, now being up to $0.7 \%$ in Finland $[17,19]$.

There is also evidence that the median diagnostic delay has shortened compared with the approximately 10 years seen in many other countries, but even in Finland up to $25 \%$ of patients have an unacceptable lag of 7-59 years [2-7]. Causes for the delay in diagnosis are complex and inadequately known [2].

We therefore set out to explore the factors underlying the long diagnostic delay in celiac disease. Particular attention was devoted to the connection between the national guidelines for celiac disease and the delay. 


\section{METHODS}

\section{Participants and study design}

The study was conducted at Tampere University Hospital and the University of Tampere. First, adult patients diagnosed with biopsy-proven celiac disease were recruited by a nationwide search using newspaper advertisements and via local celiac disease societies. All celiac disease diagnoses had to be verified from the medical records. Exclusion criteria were uncertain diagnosis, diagnosis before the age of 18 years and lack of information reganrding date of diagnosis or duration of symptoms leading to it. Next, the eligible participants filled self-administered questionnaires and consented to phone interviews by a physician or a study nurse with expertise in celiac disease. Particular attention was paid to the duration and type of symptoms before diagnosis, date and place of diagnosis, family history of the disease and presence of celiac disease-associated co-morbidities such as type 1 diabetes and thyroidal disease, or other significant co-morbidities such as malignancy and neurological, psychiatric and musculoskeletal disease. According to baseline presentation, the patients were further categorized into 1. subjects with gastrointestinal (abdominal pain, diarrhea, abdominal distention, constipation, reflux, nausea, malabsorption, weight loss) symptoms; 2. subjects with extraintestinal (e.g. dermatitis herpetiformis, tiredness, neurological symptoms) symptoms, and 3. those who were detected by screening in at-risk groups. All self-reported retrospective information was verified from the subjects' medical records. The diagnosis was considered substantially delayed if the disease-related symptoms had lasted more than ten years before diagnosis [5].

The study protocol was approved by the Ethics Committee of Tampere University Hospital. All study participants gave written informed consent.

\section{Statistics}

Binary logistic regression analysis was used to identify factors associated with delay as follows: First, univariable analysis was conducted with each variable in question. Next, multivariable analysis was performed with variables found to have significant association in the univariable analysis. The results 
are presented as percentages and odds ratios (OR) with $95 \%$ confidence intervals. A P value less than 0.05 was considered statistically significant. All statistical calculations were performed using IBM SPSS Statistics 19 (New York, NY, USA).

\section{RESULTS}

Of the altogether 922 volunteers willing to participate, 825 were eligible and included in further analyzes. Of those who were excluded, 62 lacked information regarding the duration of symptoms before celiac disease diagnosis and 14 date of diagnosis; in 21 cases the diagnosis could not be verified. Median age at diagnosis was 44 (range 18-81) years, and $76 \%$ of the 825 participants were females. Gastrointestinal symptoms remained the main clinical presentation in $52 \%$ of males and $73 \%$ of females, while $24 \%$ and $9 \%$ evinced some extraintestinal presentation and $24 \%$ and $18 \%$ were detected by screening in at-risk groups (Table 1). Dermatitis herpetiformis was present in $23 \%$ of males and $8 \%$ of females. There was a strong secular trend in the site of diagnosis, as it has markedly shifted from tertiary centres to primary and secondary health care over time (Figure 1).

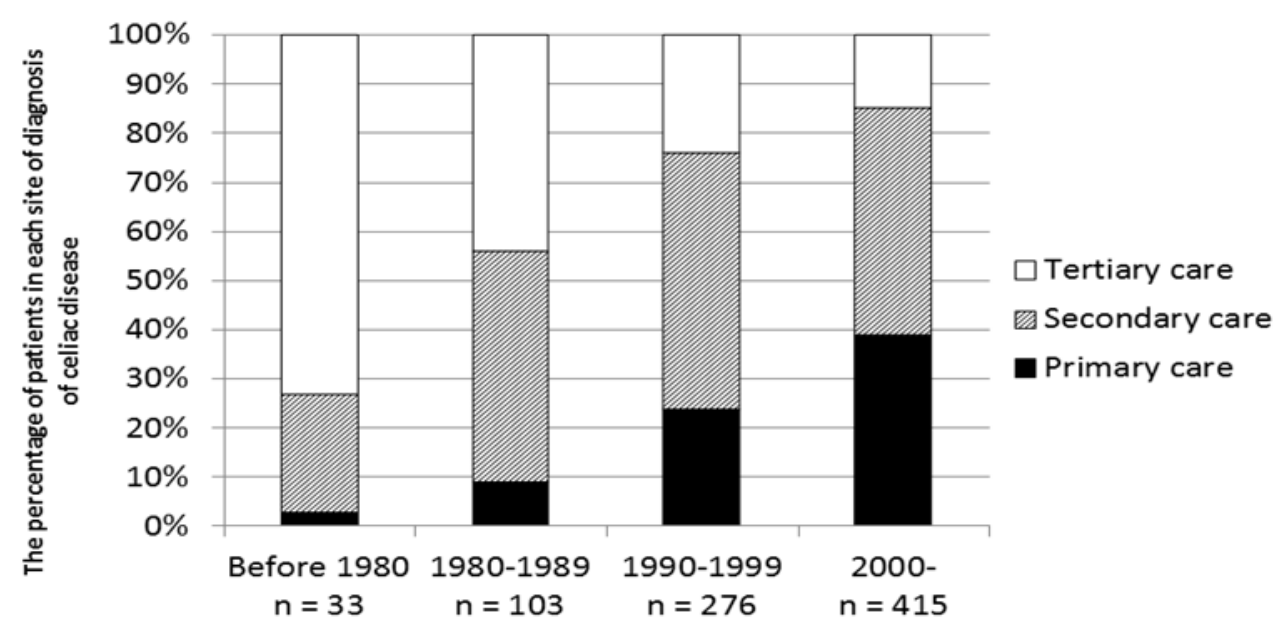

Figure 1. Development of the site of celiac disease diagnosis over time. 
Table 1. Association between clinical characteristics, place and time of diagnosis, presence of risk factors and delayed diagnosis ${ }^{\mathrm{a}}$ in 825 patients with celiac disease

\begin{tabular}{|c|c|c|c|c|c|}
\hline & $\mathrm{n}$ & Diagnostic delay, $\%$ & Odds ratio & $95 \% \mathrm{CI}$ & $P$ value \\
\hline \multicolumn{6}{|l|}{ Gender } \\
\hline Male & 198 & 23 & 1 & & \\
\hline Female & 627 & 34 & 1.79 & $1.23-2.59$ & 0.002 \\
\hline \multicolumn{6}{|l|}{ Clinical presentation } \\
\hline Gastrointestinal $^{\mathrm{b}}$ & 559 & 35 & 1 & & \\
\hline Extraintestinal $^{c}$ & 106 & 30 & 0.80 & $0.51-1.25$ & 0.316 \\
\hline Screen-detected ${ }^{\mathrm{d}}$ & 160 & 20 & 0.46 & $0.30-0.70$ & $<0.001$ \\
\hline \multicolumn{6}{|l|}{ Dermatitis herpetiformis } \\
\hline Yes & 95 & 28 & 1 & & \\
\hline No & 730 & 32 & 1.19 & $0.74-1.91$ & 0.474 \\
\hline \multicolumn{6}{|l|}{ Site of diagnosis } \\
\hline Primary care & 234 & 30 & 1 & & \\
\hline Secondary care & 389 & 30 & 1.00 & $0.69-1.41$ & 0.944 \\
\hline Tertiary care & 199 & 36 & 1.30 & $0.87-1.95$ & 0.198 \\
\hline \multicolumn{6}{|c|}{ Calendar period of diagnosis } \\
\hline 2000- & 415 & 27 & 1 & & \\
\hline $1990-1999$ & 276 & 34 & 1.44 & $1.03-2.00$ & 0.031 \\
\hline $1980-1989$ & 101 & 45 & 2.20 & $1.41-3.45$ & 0.001 \\
\hline Before 1980 & 33 & 30 & 1.19 & $0.55-2.58$ & 0.658 \\
\hline \multicolumn{6}{|l|}{ Diagnosis after $1997^{\mathrm{e}}$} \\
\hline Yes & 478 & 28 & 1 & & \\
\hline No & 347 & 37 & 1.55 & $1.15-2.09$ & 0.004 \\
\hline \multicolumn{6}{|l|}{ Celiac disease in family } \\
\hline No & 283 & 37 & 1 & & \\
\hline Yes & 537 & 28 & 0.68 & $0.50-0.93$ & 0.014 \\
\hline
\end{tabular}

\footnotetext{
${ }^{\text {a }}$ Symptoms lasting 10 years or more before diagnosis of celiac disease

${ }^{\mathrm{b}}$ Diarrhea, abdominal pain or constipation, reflux, nausea, malabsorption

${ }^{\mathrm{c}}$ Dermatitis herpetiformis, tiredness, joint pains, neurological symptoms

${ }^{\mathrm{d}}$ Celiac disease in first-degree relatives, presence of autoimmune disorder

${ }^{\mathrm{e}}$ After the first national Current Care Guidelines for celiac disease

CI, confidence interval
} 
In total, 261 (32\%) out of 825 patients had diagnostic delay of 10 years or more. In univariable analysis female gender, celiac disease diagnosis before the year 2000 and diagnosis before the first national Current Care Guidelines was significantly associated with diagnostic delay (Table 1). In contrast, significant protecting factors were male gender, celiac disease detected by screening and family history of celiac disease. There was no association between long diagnostic delay and age at diagnosis, site of diagnosis or presence of dermatitis herpetiformis (Table 1).

The association between concomitant clinical conditions and diagnostic delay in celiac disease is shown in Table 2. A significant association was found between long delay and the presence of musculoskeletal or neurologic disease. In contrast, there was no association between long delay and presence of concomitant psychiatric or gastroenterological disease, osteoporotic fracture, malignancy, type 1 diabetes or thyroidal disease (Table 2).

Altogether $559(68 \%)$ out of the 825 subjects reported gastrointestinal symptoms before the diagnosis. Presentations significantly associated with long delay were diarrhea, abdominal pain and malabsorption. In contrast, no association was seen between the delay and weight loss, abdominal distention, constipation, reflux and nausea (Table 3).

In multivariable analysis, a statistically significant association was observed between long diagnostic delay and the presence of some musculoskeletal disorder $(\mathrm{p}=0.014)$, abdominal pain $(\mathrm{p}<0.001)$ and malabsorption $(\mathrm{p}<0.001)$. There was also a non-significant trend towards a reduced proportion of delayed diagnoses after the introduction of the first Current Care Guidelines in $1997(\mathrm{p}=0.063)$. 
Table 2. Association between presence of concomitant 2 linical condition and delayed diagnosis ${ }^{\mathrm{a}}$ in 825 patients with celiac disease

$\mathrm{n} \quad \begin{gathered}\text { Diagnostic } \\ \text { delay, } \%\end{gathered}$ Odds ratio $\quad 95 \% \mathrm{CI} \quad \mathrm{P}$ value

Any malignancy

$\begin{array}{lccccc}\text { No } & 781 & 32 & 1 & & \\ \text { Yes } & 42 & 26 & 0.75 & 0.37-1.52 & 0.431\end{array}$

Psychiatric disease

$\begin{array}{lrrrrr}\text { No } & 790 & 30 & 1 & & \\ \text { Yes } & 34 & 40 & 1.75 & 0.78-3.49 & 0.115\end{array}$

Neurologic disease ${ }^{b}$

$\begin{array}{lllcll}\text { No } & 718 & 30 & 1 & & \\ \text { Yes } & 107 & 40 & 1.54 & 1.02-2.34 & 0.043\end{array}$

Gastroenterological disease $\mathrm{c}^{\mathrm{c}}$

$\begin{array}{lrrrrr}\text { No } & 290 & 28 & 1 & & \\ \text { Yes } & 535 & 39 & 1.28 & 0.95-1.74 & 0.108\end{array}$

Musculoskeletal disease $^{\mathrm{d}}$

$\begin{array}{lrrrrr}\text { No } & 570 & 28 & 1 & & \\ \text { Yes } & 254 & 39 & 1.61 & 1.12-2.20 & 0.003\end{array}$

Osteoporotic fracture

$\begin{array}{lccccc}\text { No } & 792 & 31 & 1 & & \\ \text { Yes } & 31 & 45 & 1.83 & 0.89-3.77 & 0.102\end{array}$

Type 1 diabetes

$\begin{array}{lccccc}\text { No } & 808 & 32 & 1 & & \\ \text { Yes } & 17 & 29 & 0.90 & 0.31-2.58 & 0.842\end{array}$

Thyroidal disease

$\begin{array}{lllcll}\text { No } & 688 & 31 & 1 & & \\ \text { Yes } & 137 & 34 & 1.16 & 0.79-1.71 & 0.462\end{array}$

${ }^{a}$ Symptoms for 10 years or more before diagnosis of celiac disease

The most common presentations were; ${ }^{\mathrm{b}}$ Transient ischemic attacks, dementia, neuropathy, migraine, epilepsy; ${ }^{\mathrm{c}}$ Lactose-intolerance, food allergy, gastro- esophageal reflux, diverticulosis, diaphragmatic hernia; ${ }^{\mathrm{d}}$ Osteoporosis or osteopenia, arthritis, fibromyalgia, discus prolapse

CI, confidence interval 
Table 3. Association between the presence of different gastrointestinal symptoms before diagnosis and delayed diagnosis ${ }^{\mathrm{a}}$ in 825 patients with celiac disease

\begin{tabular}{|c|c|c|c|c|c|}
\hline & $\mathrm{n}$ & $\begin{array}{c}\text { Diagnostic } \\
\text { delay, } \%\end{array}$ & $\begin{array}{l}\text { Odds } \\
\text { ratio }\end{array}$ & $95 \% \mathrm{CI}$ & $\mathrm{P}$ value \\
\hline \multicolumn{6}{|l|}{ Diarrhea } \\
\hline No & 579 & 29 & 1 & & \\
\hline Yes & 246 & 38 & 1.53 & $1.12-2.09$ & 0.008 \\
\hline \multicolumn{6}{|c|}{ Weight loss } \\
\hline No & 701 & 31 & 1 & & \\
\hline Yes & 124 & 33 & 1.08 & $0.72-1.62$ & 0.711 \\
\hline \multicolumn{6}{|c|}{ Abdominal pain } \\
\hline No & 462 & 25 & 1 & & \\
\hline Yes & 363 & 40 & 1.98 & $1.47-2.67$ & $<0.001$ \\
\hline \multicolumn{6}{|c|}{ Abdominal distension } \\
\hline No & 625 & 35 & 1 & & \\
\hline Yes & 200 & 31 & 1.19 & $0.85-1.67$ & 0.317 \\
\hline \multicolumn{6}{|l|}{ Reflux } \\
\hline No & 772 & 32 & 1 & & \\
\hline Yes & 53 & 26 & 0.76 & $0.41-1.43$ & 0.399 \\
\hline \multicolumn{6}{|c|}{ Constipation } \\
\hline No & 750 & 31 & 1 & & \\
\hline Yes & 75 & 36 & 1.24 & $0.76-2.04$ & 0.395 \\
\hline \multicolumn{6}{|c|}{ Malabsorption } \\
\hline No & 593 & 27 & 1 & & \\
\hline Yes & 232 & 45 & 2.27 & $1.64-3.10$ & $<0.001$ \\
\hline \multicolumn{6}{|l|}{ Nausea } \\
\hline No & 52 & 32 & 1 & & \\
\hline Yes & 773 & 31 & 0.96 & $0.52-1.76$ & 0.890 \\
\hline
\end{tabular}

${ }^{a}$ Symptoms for 10 years or more before diagnosis of celiac disease

CI, confidence interval 


\section{DISCUSSION}

An important finding in the present study was that the proportion of subjects with a diagnostic delay of 10 years or more in celiac disease has been significantly reduced within the past decades and also since the introduction of the first national guidelines for celiac disease in 1997. At the same time, the site of the diagnosis shifted markedly from secondary and tertiary to primary care. These findings, together with the fact that there was no significant difference in the prevalence of long delay between the different health-care sites, indicate that the regular and systematic training of primary care physicians in early recognition of celiac disease has been successful and encourages to continue [17, 18]. We believe that such a wide-scale decentralization of the diagnostics is a necessity, as the number of new celiac disease diagnoses is on a steep increase in most Western countries [20]. Furthermore, intensified awareness among health-care professionals and subsequent active case-finding has proved to be a costeffective alternative to population-based mass-screening in celiac disease [3]. Somewhat contradictory to our findings, some recent studies in other countries have indicated that non-gastroenterologists and other physicians with less expertise with celiac disease may have significantly poorer adherence to the published diagnostic guidelines for the condition than experts [21, 22]. These findings emphasize that

the re-organization with possible decentralization of celiac disease diagnostics must be implemented in conjunction with a systematic education of physicians likely to encounter undetected celiac disease patients in their daily practice.

In univariable analysis here we found several factors which were associated with long diagnostic delay in celiac disease, some of them being rather surprising. Quite opposite to our expectations, males were significantly less at risk of long delay than females. One explanation for this might be that a greater proportion of males than females were detected by serological screening in at-risk groups for celiac disease. Also, extraintestinal symptoms were almost three times more common in males and, even though there was no statistically significant difference here, can be easier to find. This can be due for example to the rather straightforward diagnosis of skin symptoms of dermatitis herpetiformis, which is more common among males [23]. Also, males in general seek less medical advice until disease-related symptoms become very severe [24]. Thus, even though males had long diagnostic delay less often than 
females, it is possible that a higher proportion of males remain unrecognized. Moreover, particulary in female celiac disease patients the former irritable bowel syndrome diagnosis is common, this often in fact being unrecognized celiac disease with delayed diagnosis [25, 26].

Of concomitant medical conditions, the presence of a neurologic or musculoskeletal disease was significantly associated with a long diagnostic delay. As one plausible explanation here, it is likely that the presence of a previous serious disease distracts from diagnosis of another. In addition, several recent studies have shown that different neurological manifestations, such as ataxia and neuropathy are frequently implicated with celiac disease [27]. It is important that neurologists and general practitioners learn to know celiac disease as a possibility behind a patient's unspecific neurological symptoms. Likewise, physicians should recognize that various musculoskeletal symptoms, such as joint pains and osteoporosis, are also common and possible the sole finding in celiac disease patients [28, 29].

It was surprising that one of the most characteristic and classic signs of celiac disease, malabsorption, increased the risk for long delay. Iron deficiency anemia is the most common form of malabsorption in celiac disease [1]. As it is often the only sign of untreated celiac disease, the presence of unexplained anemia should always lead to a suspicion and prompt exclusion of the disorder [30, 31]. Similarly to malabsorption, other particulary typical symptoms of untreated celiac disease, diarrhea and abdominal pain, were associated with excessive delay in the present study; abdominal pain remained significant even after multivariable analysis. This rather unexpected result might be partly explained by a recall bias in the retrospective design, as the duration of these burdensome and typical symptoms of celiac disease is easily overestimated compared to milder or atypical symptoms. More research is evidently needed to confirm these unexpected associations.

Strengths of the present study were the nationwide approach and the large number of participants with well-verified biopsy-proven celiac disease. Further, the clinical data were collected meticulously both by expert interviews and from medical records. The variable clinical presentation of celiac disease was also taken into account. Nevertheless, there were also certain limitations. First, the majority of study subjects were members of patient support organizations, which might have caused selection bias. On the other hand, approximately $70 \%$ of all celiac disease patients in Finland are members of such 
organizations; we thus believe our results to be representative $[17,33]$. Second, the retrospective design and long period of time covered by the study made it vulnerable to a number of confounding factors; also only a few associations remained significant after multivariable analysis. The threshold of 10 years or more used here for considerably delayed diagnosis is also somewhat artificial; however, we would maintain that such a long delay is in any case unacceptable. There is moreover evidence that a delay this long is associated with the development of celiac disease-associated malignancies [5]. The precise impact of the national Current Care Guidelines in this progress could not be evaluated even though the directives are a possible factor in reducing the diagnostic delay. Nevertheless, these guidelines are intended mainly for the general practitioners, and we believe that they will augment the diagnostics at population level.

To conclude, an unacceptably long diagnostic delay in celiac disease has become less common in Finland over the past decades. It was surprising that the classic diagnostic clues to celiac disease, gastrointestinal symptoms and malabsorption, did not reduce but on the contrary were associated with a higher risk of long diagnostic delay. The shift of diagnostics from secondary and tertiary to primary care has not resulted in longer delays. National guidelines for the diagnosis of celiac disease are important in these circumstances. 


\section{Acknowledgements}

This study was supported by the Academy of Finland Research Council for Health, the Competitive State Research Financing of the Expert Responsibility Areas of of Tampere University Hospital (Grants 9P060, 9R018, and Seinäjoki Central Hospital Grant VTR16), the Sigrid Juselius Foundation, the Foundation for Paediatric Research, the Finnish Medical Foundation and Elna Kaarina Savolainen's and Seppo Nieminen's funds allocated for the development of cancer treatment.

Declaration of interest: The authors report no conflict of interest. The authors alone are responsible for the content and writing of the paper. 


\section{REFERENCES}

[1] Di Sabatino A, Corazza GR. Coeliac disease. Lancet 2009;373:1480-93.

[2] Norstrom F, Lindholm L, Sandstrom O, Nordyke K, Ivarsson A. Delay to celiac disease diagnosis and its implications for health-related quality of life. BMC Gastroenterol 2011;11:118,230X-11-118.

[3] Hershcovici T, Leshno M, Goldin E, Shamir R, Israeli E. Cost effectiveness of mass screening for coeliac disease is determined by time-delay to diagnosis and quality of life on a gluten-free diet. Aliment Pharmacol Ther 2010;31:901-10.

[4] Ukkola A, Kurppa K, Collin P, Huhtala H, Forma L, Kekkonen L, et al. Use of health care services and pharmaceutical agents in coeliac disease: A prospective nationwide study. BMC Gastroenterology 2012;12:136.

[5] Green PHR, Stavropoulos SN, Panagi SG, Goldstein SL, Mcmahon DJ, Absan H, et al. Characteristics of adult celiac disease in the USA: Results of a national survey. Am J Gastroenterol 2001;96:126-31.

[6] Cranney A, Zarkadas M, Graham ID, Butzner JD, Rashid M, Warren R, et al. The canadian celiac health survey. Digestive Diseases \& Sciences 2007;52:1087-95.

[7] Gray AM, Papanicolas IN. Impact of symptoms on quality of life before and after diagnosis of coeliac disease: Results from a UK population survey. BMC Health Services Research 2010;10:105.

[8] Mattila E, Kurppa K, Ukkola A, Collin P, Huhtala H, Forma L, et al. Burden of illness and use of health care services before and after celiac disease diagnosis in children. Journal of Pediatric Gastroenterology \& Nutrition 2013;57:53-6.

[9] Long KH, Rubio-Tapia A, Wagie AE, Melton LJ,3rd, Lahr BD, Van Dyke CT, et al. The economics of coeliac disease: A population-based study. Aliment Pharmacol Ther 2010;32:261-9.

[10] Corazza GR, Di Sario A, Cecchetti L, Tarozzi C, Corrao G, Bernardi M, et al. Bone mass and metabolism in patients with celiac disease. Gastroenterology 1995;109:122-8.

[11] Gasbarrini A, Torre ES, Trivellini C, De Carolis S, Caruso A, Gasbarrini G. Recurrent spontaneous abortion and intrauterine fetal growth retardation as symptoms of coeliac disease. Lancet 2000;356:399-400. 
[12] Zugna D, Richiardi L, Stephansson O, Cnattingius S, Ludvigsson JF. Mortality rate in children born to mothers and fathers with celiac disease: A nationwide cohort study. Am J Epidemiol 2013;177:1348-55.

[13] Holmes GK, Prior P, Lane MR, Pope D, Allan RN. Malignancy in coeliac disease--effect of a gluten free diet. Gut 1989;30:333-8.

[14] Lebwohl B, Granath F, Ekbom A, Smedby KE, Murray JA, Neugut AI, et al. Mucosal healing and risk for lymphoproliferative malignancy in celiac disease: A population-based cohort study. Ann Intern Med 2013;159:169-75.

[15] Paarlahti P, Kurppa K, Ukkola A, Collin P, Huhtala H, Maki M, et al. Predictors of persistent symptoms and reduced quality of life in treated coeliac disease patients: A large cross-sectional study. BMC Gastroenterology 2013;13:75.

[16] Current care guideline: Coeliac disease http://www.terveysportti.fi/dtk/ltk/koti?p_haku=keliakia. 2013 [cited 20.10.2013].

[17] Virta LJ, Kaukinen K, Collin P. Incidence and prevalence of diagnosed coeliac disease in finland: Results of effective case finding in adults. Scand J Gastroenterol 2009;44:933-8.

[18] Collin P, Huhtala H, Virta L, Kekkonen L, Reunala T. Diagnosis of celiac disease in clinical practice: Physician's alertness to the condition essential. J Clin Gastroenterol 2007;41:152-6.

[19] Vilppula A, Kaukinen K, Luostarinen L, Krekela I, Patrikainen H, Valve R, et al. Increasing prevalence and high incidence of celiac disease in elderly people: A populationbased study. BMC Gastroenterology 2009;9:49.

[20] Lohi S, Mustalahti K, Kaukinen K, Laurila K, Collin P, Rissanen H, et al. Increasing prevalence of coeliac disease over time. Aliment Pharmacol Ther 2007;26:1217-25.

[21] Lebwohl B, Kapel RC, Neugut AI, Green PH, Genta RM. Adherence to biopsy guidelines increases celiac disease diagnosis. Gastrointest Endosc 2011;74:103-9.

[22] Parakkal D, Du H, Semer R, Ehrenpreis ED, Guandalini S. Do gastroenterologists adhere to diagnostic and treatment guidelines for celiac disease?. J Clin Gastroenterol 2012;46:e12-

[23] Salmi TT, Hervonen K, Kautiainen H, Collin P, Reunala T. Prevalence and incidence of dermatitis herpetiformis: A 40-year prospective study from finland. Br J Dermatol 2011;165:354-9.

[24] Pedersen AF, Olesen F, Hansen RP, Zachariae R, Vedsted P. Social support, gender and patient delay. Br J Cancer 2011;104:1249-55. 
[25] Card TR, Siffledeen J, West J, Fleming KM. An excess of prior irritable bowel syndrome diagnoses or treatments in celiac disease: Evidence of diagnostic delay. Scand $\mathbf{J}$ Gastroenterol 2013;48:801-7.

[26] Lovell RM, Ford AC. Effect of gender on prevalence of irritable bowel syndrome in the community: Systematic review and meta-analysis. Am J Gastroenterol 2012;107:991-1000.

[27] Jackson JR, Eaton WW, Cascella NG, Fasano A, Kelly DL. Neurologic and psychiatric manifestations of celiac disease and gluten sensitivity. Psychiatr Q 2012;83:91-102.

[28] Vereckei E, Mester A, Hodinka L, Temesvari P, Kiss E, Poor G. Back pain and sacroiliitis in long-standing adult celiac disease: A cross-sectional and follow-up study. Rheumatol Int 2010;30:455-60.

[29] Kurppa K, Collin P, Sievanen H, Huhtala H, Maki M, Kaukinen K. Gastrointestinal symptoms, quality of life and bone mineral density in mild enteropathic coeliac disease: A prospective clinical trial. Scand J Gastroenterol 2010;45:305-14.

[30] Looker AC, Dallman PR, Carroll MD, Gunter EW, Johnson CL. Prevalence of iron deficiency in the united states. JAMA 1997;277:973-6.

[31] Bottaro G, Cataldo F, Rotolo N, Spina M, Corazza GR. The clinical pattern of subclinical/silent celiac disease: An analysis on 1026 consecutive cases. Am J Gastroenterol 1999;94:691-6.

[32] Finnish celiac society http://www.keliakialiitto.fi/liitto/jarjesto/. 2008 [cited 26.11.2013]. 